Article

\title{
Powdered Ceramsite and Powdered Limestone Use in Aerobic Granular Sludge Technology
}

\author{
Joanna Czarnota ${ }^{1, * \mathbb{D}}$, Janusz A. Tomaszek ${ }^{1}$, Adam Masłoń ${ }^{1} \mathbb{D}$, Adam Piech ${ }^{2}$ and \\ Grzegorz Łagód 3,* (D) \\ 1 Department of Environmental Engineering and Chemistry, Rzeszow University of Technology, \\ 6 Powstańców Warszawy Av, 35-959 Rzeszów, Poland; tomaszek@prz.rzeszow.pl (J.A.T.); \\ amaslon@prz.edu.pl (A.M.) \\ 2 Department of Water Purification and Protection, Rzeszow University of Technology, 6 Powstańców \\ Warszawy Av, 35-959 Rzeszów, Poland; apiech@prz.edu.pl \\ 3 Faculty of Environmental Engineering, Lublin University of Technology, Nadbystrzycka 40B, \\ 20-618 Lublin, Poland \\ * Correspondence: askalucz@prz.edu.pl (J.C.); g.lagod@pollub.pl (G.Ł.); Tel.: +48-17-865-1278 (J.C.); \\ +48-81-538-4322 (G.Ł.)
}

Received: 20 June 2020; Accepted: 31 August 2020; Published: 3 September 2020

\begin{abstract}
The effects of two powdered mineral materials (powdered ceramsite and powdered limestone) on aerobic granulation of sludge were evaluated. The experiment was conducted on a laboratory scale bioreactors treating wastewater for 89 days. Three granular sequencing batch reactors (GSBRs) were operated at the lowest optimal organic loading rate (OLR) of $2.55 \mathrm{~g} \mathrm{COD} /(\mathrm{L} \cdot \mathrm{d})$. In the control reactor (R1), the mean diameter (d) of the biomass ranged from 124.0 to $210.0 \mu \mathrm{m}$, and complete granulation was not achieved. However, complete granulation did occur in reactors to which either ceramsite $(251.9 \mu \mathrm{m}<\mathrm{d}<783.1 \mu \mathrm{m})$ or limestone $(246.0 \mu \mathrm{m}<\mathrm{d}<518.9 \mu \mathrm{m})$ was added. Both powdered materials served as a ballast for the sludge flocs making up the seed sludge. Ceramsite particles also acted as microcarriers of granule-forming biomass. The granules in the reactors with added powdered materials had nonfibrous and smoother surfaces. The reactor with ceramsite exhibited the highest average efficiencies for COD, total nitrogen, and total phosphorus removal $(85.4 \pm 5.4 \%, 56.6 \pm 10.2 \%$, and $56.8 \pm 9.9 \%$, respectively). By contrast, the average nitrification efficiency was $95.1 \pm 12.8 \%$.
\end{abstract}

Keywords: powdered ceramsite; powdered limestone; AGS technology; organic loading rate; wastewater treatment

\section{Introduction}

The use of aerobic granular sludge (AGS) is a promising and relatively new technology for the treatment of different types of wastewater; it allows for the simultaneous removal of carbon, nitrogen, phosphorus, and other pollutants in a single reactor [1-3]. Importantly, the operating conditions supporting aerobic granulation are strongly determined by various parameters, including the reactor configuration, seed sludge, settling time, organic loading rate (OLR), volume exchange ratio, hydrodynamic shear force, feast-famine regime, cycle time, and other environmental conditions (notably, pH and temperature) [4-6]. Most reports on successful granulation have shown that a high OLR is critical to the development and maturation of aerobic granules [7-9]. Higher OLR facilitates granule formation [9-12]. According to a literature review, the optimal OLR of a granular sequencing batch reactor (GSBR) is $2.50 \mathrm{~g} \mathrm{COD/(L \cdot d)} \mathrm{[13]} \mathrm{or} \mathrm{should} \mathrm{be} \mathrm{in} \mathrm{the} \mathrm{range} 2.50-7.50 \mathrm{~g} \mathrm{COD} /(\mathrm{L} \cdot \mathrm{d})[14,15]$. In treatment of wastewater with a lower chemical oxygen demand (COD) concentration, a higher organic load can be obtained by shortening the cycle time $[10,16]$. At a low OLR, sludge granulation 
also requires a relatively long startup period (more than three months) [10]. Despite considerable research, new methods and means of improving AGS technology are still being sought. The objective is to improve biogranulation and stability of aerobic granules, especially through improved AGS formation in low-strength wastewater [6,14].

To date, research on improving AGS technology has involved chemical coagulants [17], dosage of granule fragments [18,19], and powdered materials, both mineral (Table 1) [4,11,20-22] and organic [10,23-28]. It should be emphasized that in addition to the use of metal ions and flocculants, organic materials are most often described in the latest review articles $[29,30]$, the subject of which concerns strategies implemented to improve the biogranulation process.

Table 1. Physical properties of powdered mineral materials used in previous aerobic granular sludge (AGS) research.

\begin{tabular}{ccccc}
\hline Mineral Material & Specific Surface Area $\left(\mathbf{m}^{\mathbf{2}} \mathbf{g}\right)$ & Density $\left(\mathbf{g} / \mathbf{c m}^{\mathbf{3}}\right)$ & Diameter $(\boldsymbol{\mu m})$ & Reference \\
\hline Basalt & Large $*$ & n.d. & from 212 to 300 & {$[20]$} \\
Zeolite & Large & n.d. & from 150 to 300 & {$[22]$} \\
Bivalve shell carrier & Large & 1.45 & from 150 to 220 & {$[21,31]$} \\
Yellow earth & n.d. & n.d. & above 270 & {$[4]$} \\
Ceramsite & 5.183 & 2.6182 & to 200 & {$[11,15]$} \\
\hline
\end{tabular}

* no numeric value, only term "large" was used. n.d.-no data.

According to the literature, powdered materials added to a GSBR should have a sufficiently large specific surface area and be sufficiently heavy and spherical. Moreover, they should settle out rapidly enough and also be stably suspended with biomass in the reactor [15,31]. In AGS technology, these materials (both mineral and organic) are microcarriers of biomass that forms aggregates [15,31]. Additionally, the use of mineral and organic powdered materials can shorten the time required for activated sludge to granulate because they act as nuclei that induce the aggregation of microorganisms [25]. Furthermore, divalent cations (i.e., $\mathrm{Ca}^{2+}, \mathrm{Mg}^{2+}$ ) in the mineral materials may participate in the formation of aggregate matrices [32,33].

Application of powdered materials in AGS technology causes more rapid biomass sedimentation, reduces the time required for biogranulation, and decreases the amount of total suspended solids at the outlet. Furthermore, it significantly impacts lower values for the sludge volume index (SVI), granules density, and stability of granules during long-term reactor operation [21,24,25,34].

The main aim of this work was to evaluate the reasonability of powdered ceramsite and powdered limestone use in the aspect of improving the aerobic granular sludge technology. Compared to state-of-the-art materials, the novelty of the conducted research should be emphasized, because it allows us to compare the impacts of two different and hitherto unused powdered mineral materials on AGS technology. Using statistical analysis, a comparison of biomass parameters and efficiency of wastewater treatment in two reactors with addition of different powdered mineral materials in relation to the control reactor was made. In addition, the relationships between selected biomass parameters in individual reactors were determined, which clearly confirmed that use of these materials is reasonable. Note that the experiments were conducted in GSBRs with the lowest optimal OLR. Our own preliminary research on the application of powdered ceramsite in AGS technology is described in the article Czarnota et al. [15].

\section{Materials and Methods}

\subsection{Powdered Materials}

The study used two powdered mineral materials, ceramsite (PK) and limestone (PL). Powdered ceramsite is a waste fraction from the production of ceramic aggregates, and its natural grain size ranges from 0.39 to $200 \mu \mathrm{m}[11,15,33]$. A powdered fraction of limestone was obtained by grinding a coarse material mechanically and then sieving it through a $0.2 \mathrm{~mm}$ sieve. The selected powdered materials 
were characterized in terms of various physical and chemical properties (Table 2). The present study uses materials in which smaller particles are dominant. The specific surface areas of these materials were smaller than the surface areas of materials (especially organic materials) used in the previous AGS research. The particles were assumed to function mainly as a ballast for sludge flocs, with only a limited role as a biomass microcarrier. In addition, the analysis followed up on previous reports [35-37] of a positive impact of cations such as $\mathrm{Ca}^{2+}, \mathrm{Mg}^{2+}$, and $\mathrm{Fe}^{3+}$ on the biogranulation process.

Table 2. Physicochemical properties of the applied powdered materials (adopted according to [33]).

\begin{tabular}{ccc}
\hline Parameter, Units & Powdered Ceramsite (PK) & Powdered Limestone (PL) \\
\hline Specific surface area $\left(\mathrm{S}_{\mathrm{BET}}\right), \mathrm{m}^{2} / \mathrm{g}$ & 5.183 & 1.760 \\
Sphericity/shape & low sphericity & hight sphericity \\
Granulation: $\mathrm{d}_{90} ; \mathrm{d}_{50} ; \mathrm{d}_{10}, \mu \mathrm{m}$ & $85.279 ; 24.110 ; 3.643$ & $189.720 ; 33.915 ; 1.865$ \\
Apparent density, $\mathrm{g} / \mathrm{cm}^{3}$ & 2.6182 & 2.1949 \\
Chemical composition, $\mathrm{mg} / \mathrm{g}$ & Ca: $75.90 ; \mathrm{Fe}: 45.15 ;$ & Ca: $691.04 ; \mathrm{Fe}: 1.68 ;$ \\
& $\mathrm{Mg}: 21.61 ; \mathrm{Si}: 216.30$ & Mg: $4.61 ; \mathrm{Si}: 5.58$ \\
Substance leaching, $\mu \mathrm{g} / \mathrm{g}$ & $\mathrm{Ca:} 451.65 ; \mathrm{Fe}: 0.50 ;$ & Ca: $87.75 ; \mathrm{Fe}: 0.21 ;$ \\
Settling velocity, $\mathrm{m} / \mathrm{h}$ & $\mathrm{Mg}: 97.87 ; \mathrm{Si}: 23.01$ & Mg: $12.67 ; \mathrm{Si}: 7.00$ \\
& approx. 9.0 & approx. 12.0 \\
\hline
\end{tabular}

\subsection{Reactor Set-Up and Operating Strategy}

Three lab-scale GSBRs with 3.0 L working volume were operated in parallel for 89 days. The parameters of experiment (geometrical configuration of reactors, flow rate, volumetric exchange ratio, hydraulic retention time, air supply, and cycle of operation) were adopted according to studies of Czarnota et al. [15]. The technical parameters of the reactors are presented in Table 3.

Table 3. Technical parameters of the reactors used in this study (adopted according to [15]).

\begin{tabular}{|c|c|c|c|}
\hline Parameter, Units & R1 & $\mathbf{R} 2$ & $\mathbf{R} 3$ \\
\hline Powdered materials & - & ceramsite & limestone \\
\hline Dosage of powdered material, $\mathrm{g} / \mathrm{L}$ & - & 3.0 & 3.0 \\
\hline Working height $(\mathrm{H})$ and internal diameter (D), $\mathrm{m}$ & \multicolumn{3}{|c|}{0.78 and $0.07(\mathrm{H} / \mathrm{D}=11.1)$} \\
\hline Average daily flow of wastewater, $\mathrm{L} / \mathrm{d}$ & 12.0 & 12.0 & 12.0 \\
\hline Amount of wastewater fed during the cycle $(\Delta \mathrm{V}), \mathrm{L}$ & 1.5 & 1.5 & 1.5 \\
\hline Volumetric exchange ratio (VER), - & 0.5 & 0.5 & 0.5 \\
\hline Hydraulic retention time (HRT), h & $6^{(*)}$ & 6 & 6 \\
\hline Cycle of operation (3 h) & \multicolumn{3}{|c|}{$\begin{array}{c}10 \mathrm{~min} \text {-feeding without stirring, } \\
160 \mathrm{~min} \text {-reaction (air supply: } 110 \mathrm{~L} / \mathrm{h}), \\
4 \mathrm{~min} \text {-settling, } 5 \mathrm{~min} \text {-decantation, } \\
1 \text { min—an idle phase }\end{array}$} \\
\hline
\end{tabular}

(*) in order to maintain the MLVSS (mixed liquor volatile suspended solids) in the reactor, it was necessary to control the value of HRT.

The first GSBR (R1—without powdered material) was a control reactor, whereas $3.0 \mathrm{~g} / \mathrm{L}$ of PK or PL were added to reactors R2 and R3, respectively (Figure 1). The construction of a single reactor used in the research has been presented in the article by Czarnota et al. [33]. 


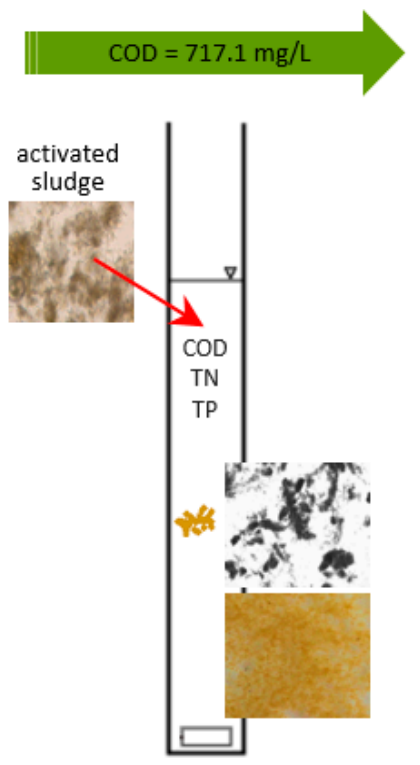

GSBR 1

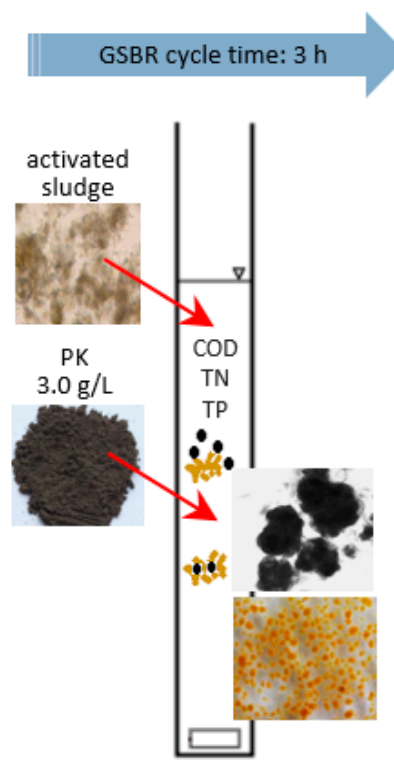

GSBR 2

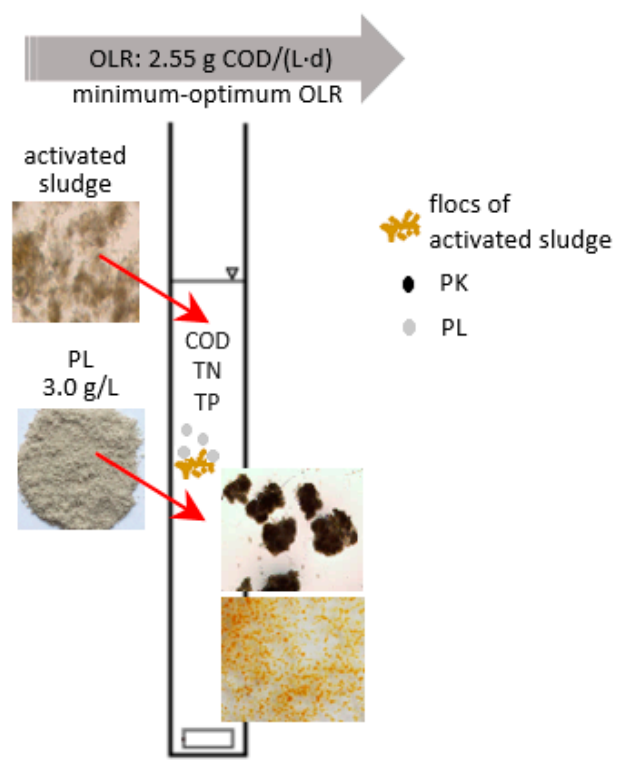

GSBR 3

Figure 1. Graphic representation of the way the research was conducted.

The airflow velocity in the reaction phase (aeration) was $0.8 \mathrm{~cm} / \mathrm{s}$, and rotameters were used to adjust this parameter. The reactors were operated automatically using time controllers. The temperature was about $20^{\circ} \mathrm{C}$ during the entire experiment.

In order to start lab-scale GSBRs, activated sludge from municipal wastewater treatment plant in Rzeszów (Poland) was drawn. The inoculum had following parameters: initial mixed liquor suspended solids (MLSS) about $6.40 \mathrm{~g}$ MLSS/L and sludge volume index $\left(\mathrm{SVI}_{30}\right)$ about $135.2 \mathrm{~mL} / \mathrm{g}$. The volume of inoculum was $1.8 \mathrm{~L} /$ volume of reactor, and the same volume was used in our own further research [11].

The study was performed using synthetic wastewater, which was prepared according to the chemical composition given by Thanh et al. [21]. The composition was as follows: glucose $(664.0 \mathrm{mg} / \mathrm{L}), \mathrm{NaHCO}_{3}(450.0 \mathrm{mg} / \mathrm{L}), \mathrm{NH}_{4} \mathrm{Cl}(150.0 \mathrm{mg} / \mathrm{L}), \mathrm{KH}_{2} \mathrm{PO}_{4}(43.0 \mathrm{mg} / \mathrm{L}), \mathrm{CaCl}_{2} \cdot 2 \mathrm{H}_{2} \mathrm{O}(30.0 \mathrm{mg} / \mathrm{L})$, $\mathrm{MgSO}_{4} \cdot 7 \mathrm{H}_{2} \mathrm{O}(12.0 \mathrm{mg} / \mathrm{L}), \mathrm{FeCl}_{3}(3.6 \mathrm{mg} / \mathrm{L})$, and $1.0 \mathrm{~mL} / \mathrm{L}$ of trace elements. The major sources of phosphorus, nitrogen, and organic compounds were potassium dihydrogen phosphate, ammonium chloride, and glucose, respectively. The experiment was conducted using various concentrations of pollutants in the influent (Table 4).

Table 4. Characteristics of wastewater used in this study.

\begin{tabular}{|c|c|c|c|c|}
\hline Parameter, Units & Minimum & Maximum & Average & Standard Deviation \\
\hline $\mathrm{COD}, \mathrm{mg} \mathrm{O}_{2} / \mathrm{L}$ & 615.0 & 785.0 & 717.1 & 62.6 \\
\hline $\mathrm{NH}_{4}{ }^{+}-\mathrm{N}, \mathrm{mg} \mathrm{N} / \mathrm{L}$ & 28.8 & 42.8 & 39.3 & 3.4 \\
\hline $\mathrm{NO}_{3}{ }^{-}-\mathrm{N}, \mathrm{mg} \mathrm{N} / \mathrm{L}$ & 0.51 & 2.99 & 1.56 & 0.61 \\
\hline $\mathrm{NO}_{2}{ }^{-}-\mathrm{N}, \mathrm{mg} \mathrm{N} / \mathrm{L}$ & 0.002 & 0.032 & 0.007 & 0.008 \\
\hline TN, mg N/L & 40.3 & 50.3 & 44.0 & 3.0 \\
\hline $\mathrm{PO}_{4}{ }^{3-}-\mathrm{P}, \mathrm{mg} \mathrm{P} / \mathrm{L}$ & 7.49 & 9.08 & 8.27 & 0.52 \\
\hline $\mathrm{TP}, \mathrm{mg} \mathrm{P} / \mathrm{L}$ & 8.55 & 11.6 & 9.73 & 1.05 \\
\hline $\mathrm{COD} / \mathrm{TN}$ ratio & 13.8 & 18.7 & 16.3 & 1.6 \\
\hline $\mathrm{COD} / \mathrm{TP}$ ratio & 53.8 & 89.7 & 74.9 & 12.8 \\
\hline
\end{tabular}

The COD value in the synthetic wastewater was $717.1 \pm 62.6 \mathrm{mg} \mathrm{O}_{2} / \mathrm{L}$, the same values figure in article Czarnota et al. [15]. Calculated OLR was approximately $2.55 \mathrm{~g} \mathrm{COD} /(\mathrm{L} \cdot \mathrm{d})$; this is the minimum value of the organic compound load that can be considered optimal for AGS technology. 


\subsection{Analytical Method}

The parameters of raw and treated wastewater, such as the COD, total nitrogen (TN), total Kjeldahl nitrogen $(\mathrm{TKN})$, ammonium-nitrogen $\left(\mathrm{NH}_{4}{ }^{+}-\mathrm{N}\right)$, nitrite-nitrogen $\left(\mathrm{NO}_{2}{ }^{-}-\mathrm{N}\right)$, nitrate-nitrogen $\left(\mathrm{NO}_{3}{ }^{-}-\mathrm{N}\right)$, total phosphorus (TP), and phosphate-phosphorus $\left(\mathrm{PO}_{4}{ }^{3-}-\mathrm{P}\right)$, were determined using photometric measurement methods according to Polish Standards (PN). These parameters were analyzed using commercial Hach Lange ${ }^{\circledR}$ test kits (for COD; Hach Berlin, Berlin, Germany), Spectroquant ${ }^{\circledR}$ Reagent Test Kits (for TN, $\mathrm{NH}_{4}{ }^{+}-\mathrm{N}, \mathrm{NO}_{2}{ }^{-}-\mathrm{N}, \mathrm{NO}_{3}{ }^{-}-\mathrm{N}, \mathrm{TP}$ and $\mathrm{PO}_{4}{ }^{3-}-\mathrm{P}$; Merck KGaA, Darmstadt, Germany), and spectrophotometers (Hach DR5000 for COD and Aquamate Thermo Spectronic for other parameters, Hach Berlin, Berlin, Germany and Thermo Fisher Scientific, Waltham, MA, USA). The dissolved oxygen (DO) and $\mathrm{pH}$ were also monitored using a DO meter (1-channel multimeter Hach HQ30d with sonde, Hach Berlin, Berlin, Germany) and $\mathrm{pH}$ meter (1-channel multimeter Hach HQ30d with pH electrode, Hach Berlin, Berlin, Germany). The biomass parameters, such as sludge volume index $\left(\mathrm{SVI}_{5}\right.$ and $\left.\mathrm{SVI}_{30}\right)$, sludge settling velocity (V), MLSS, and mixed liquor volatile suspended solids (MLVSS) were determined according to standard methods [38]. The specific oxygen uptake rate (SOUR) for biomass was determined using a methodology described by Kristensen et al. [39] and Zielińska et al. [40]. Optical microscopy (Olympus BX51, Olympus America, NY, USA) was used to observe the sludge floc and aerobic granule morphology. A method proposed by Arrojo [41], which uses the specialized CellQ software (standard version, Olympus America, NY, USA), was used to determine the aerobic granule size. The percentage share of the individual fractions (the smallest fraction is $\mathrm{d}<200 \mu \mathrm{m}$ ) was determined by relating the number of granules in a given observation range to the total number of observations (minimum 200 granules from one reactor). By calculating the average value for the granules diameters on a given day, the average granule size (d) was determined. Granular structure was identified by scanning electron microscopy (SEM) (MIRA Tescan, Tescan Orsay Holding, Brno, Czech Republic). Samples of biomass were lyophilized before the SEM analysis. In addition, computed tomography (Computer Tomograph Phoenix v|tome|x m, Baker Hughes a GE Company, Houston, TX, USA) was used to assess differences on the granule surfaces. Measurements were made using frozen samples of biomass that were insulated using a layer of styrofoam.

\subsection{Statistical Analysis}

STATISTICA 10 PL software (version 10 PL, TIBCO Software Incorporation, Palo Alto, CA, USA) was used for statistical analysis. Using Pearson's linear correlation, the relationships between pairs of variables were evaluated, and the statistical significance was determined. A significance level $\alpha$ of 0.05 was used. The Kruskal-Wallis ANOVA test was used to evaluate the differences between the averages of several groups. The probability of error related to the assumption of the hypothesis that there are differences between the averages was assumed at $5 \%(p<0.05)$.

\section{Results and Discussion}

\subsection{Biomass Concentration in the Reactors}

The MLSS after inoculation was $3.90 \mathrm{~g} / \mathrm{L}$ in each GSBR. Application of powdered materials (ceramsite in R2 and limestone in R3) increased this value to $7.38 \mathrm{~g}$ MLSS/L in R2 and $5.39 \mathrm{~g}$ MLSS/L in R3. The MLSS values measured after the five-day adaptation period were $46 \%, 43 \%$, and $28 \%$ lower than the initial values in R1, R2, and R3, respectively. The MLSS values of R2 and R3 then increased, reaching average values of $5.24 \pm 0.78$ and $5.07 \pm 1.54 \mathrm{~g} / \mathrm{L}$, respectively (Figure 2a). The MLVSS concentrations in R1, R2, and R3 decreased by $44.5 \%, 22 \%$, and $19 \%$, respectively, during the adaptation period. Further, the average MLVSS values after the adaptation period were $1.49 \pm 0.36,4.12 \pm 0.71$, and $3.94 \pm 1.39 \mathrm{~g} / \mathrm{L}$, respectively (Figure $2 \mathrm{~b}$ ). The short settling time in the GSBR cycle (4 min) favored the elution of biomass from the reactors, but the results still showed better retention in the reactors with powdered mineral materials than in the control reactor. Control of the biomass concentration 
in R1 necessitated control of the hydraulic retention time. The MLSS and MLVSS values were much higher in reactors R2 and R3 than in R1, and analysis showed that the differences in both the MLSS and MLVSS values of the reactors reached statistical significance $(p<\alpha, p=0.0000$ for MLSS, $p=0.0000$ for MLVSS). Of the two reactors operating with powdered materials, R2 exhibited the greatest stability during the tests. The increased biomass concentrations in reactors $\mathrm{R} 2$ and $\mathrm{R} 3$ were found to reflect increases in both the size and number of granules.

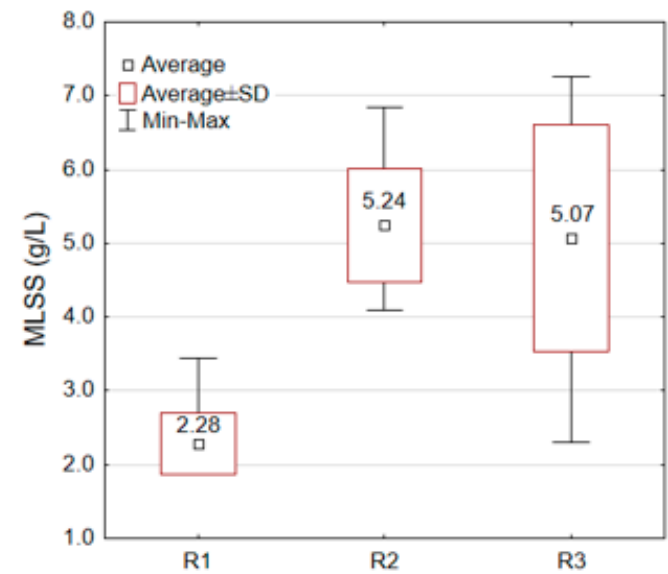

a)

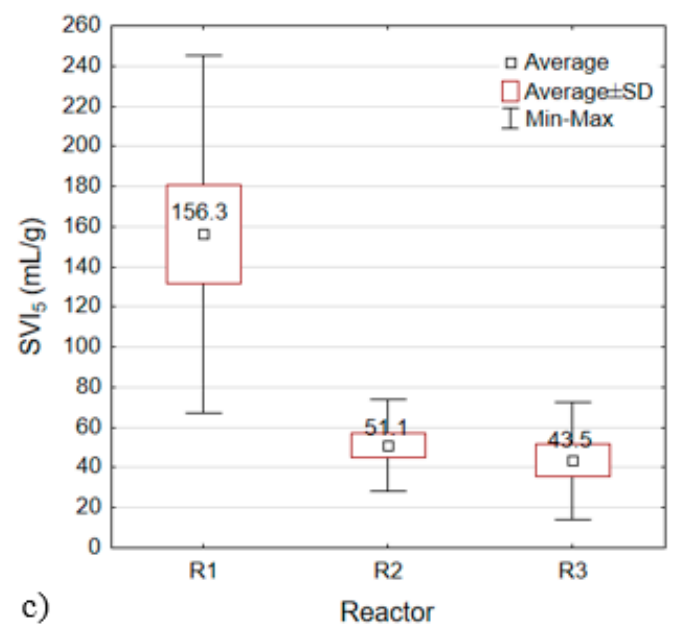

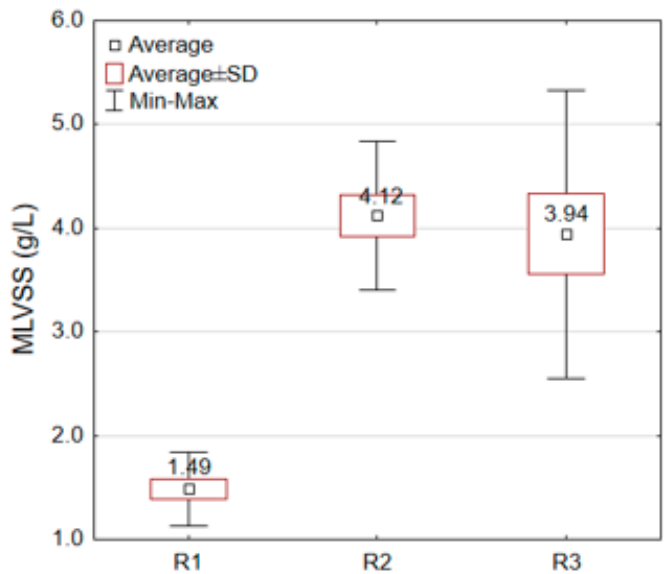

b)

Reactor

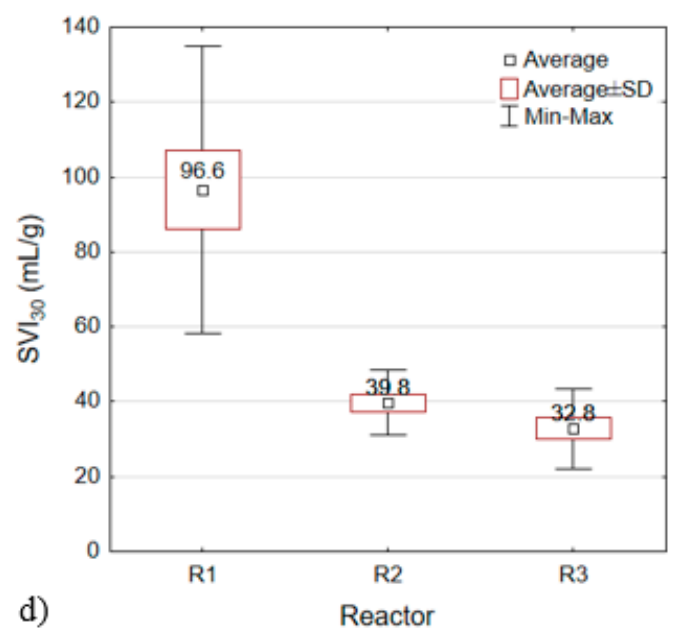

d)

Reactor

Figure 2. Average MLSS (a), MLVSS (b), $\mathrm{SVI}_{5}(\mathbf{c})$, and $\mathrm{SVI}_{30}$ (d) values of reactors.

Following inoculation of the reactors, the MLVSS/MLSS ratio was approximately 0.74 . The addition of mineral material caused that ratio to decrease to 0.53 (R2) and 0.68 (R3). After the twelfth day, when biogranulation was observed, the MLVSS/MLSS ratio was 0.76-0.84 in R2 and 0.67-0.84 in R3, indicating increases in the bioactivity of the sludge. In the control reactor, this parameter did not increase until after day 19 and reached a maximum value of 0.77 .

\subsection{Settling Properties of the Biomass}

The initial $\mathrm{SVI}_{5}$ and $\mathrm{SVI}_{30}$ values of the control reactor were 240.3 and $152.2 \mathrm{~mL} / \mathrm{g}$, respectively. By contrast, these values were significantly lower when the powdered materials were applied. In reactors $\mathrm{R} 2$ and $\mathrm{R} 3$, the initial $\mathrm{SVI}_{5}$ values were 116.5 and $166.0 \mathrm{~mL} / \mathrm{g}$, and the initial $\mathrm{SVI}_{30} \mathrm{values}$ were 52.2 and $82.6 \mathrm{~mL} / \mathrm{g}$, respectively. By the end of the study, the $\mathrm{SVI}_{5}$ values in $\mathrm{R} 1, \mathrm{R} 2$, and $\mathrm{R} 3$ were $108.8,30.7$, and $26.1 \mathrm{~mL} / \mathrm{g}$, and the $\mathrm{SVI}_{30}$ values were $92.1,30.7$, and $21.7 \mathrm{~mL} / \mathrm{g}$, respectively. The average $\mathrm{SVI}_{5}$ and $\mathrm{SVI}_{30}$ values are presented in Figure $2 \mathrm{c}, \mathrm{d}$, respectively. The reactor with powdered ceramsite 
(R2) had the most stable sludge volume, as it showed the lowest coefficient of variation for this parameter. The results of this experiment are consistent with, for example, the results reported by $\mathrm{Li}$ et al. [24], who found that the $\mathrm{SVI}_{30}$ values in a reactor with initial granular activated carbon (GAC) addition were lower throughout the process than those in a reactor without GAC. Other authors also observed that powdered materials decreased the SVI and improved the stability of granules over a prolonged period of system operation (Table 5). By contrast, Tao et al. [26] reported that the $\mathrm{SVI}_{30}$ values of two reactors (without or with GAC) did not obviously differ in or after the granulation phase. An extensive discussion of the results of own research with the literature data in this area is detailed in the publication by Czarnota et al. [33].

Table 5. Comparison of biomass parameters in reactors supported by powdered substances with those of a control reactor.

\begin{tabular}{|c|c|c|c|c|c|c|}
\hline Reactor & $\begin{array}{c}\text { OLR g } \\
\text { COD/(L·d) }\end{array}$ & $\mathrm{COD}\left(\mathrm{mg} \mathrm{O}_{2} / \mathrm{L}\right)$ & SVI (mL/g) & MLSS (g/L) & $\begin{array}{c}\text { Diameter of } \\
\text { Granules (mm) }\end{array}$ & References \\
\hline control & \multirow[t]{2}{*}{-} & \multirow{2}{*}{$\begin{array}{l}\min .1310 \\
\max .5534\end{array}$} & - & - & to $0.7^{*}$ & \multirow{2}{*}[23]{} \\
\hline with $1.0 \mathrm{~g} / \mathrm{L}$ of PAC & & & 38.0 & 5.0 & to 0.6 & \\
\hline control & \multirow{2}{*}{0.8} & \multirow{2}{*}{200} & 100.0 & approx. 3.0 & to 0.25 & \multirow{2}{*}[24]{} \\
\hline with $3.0 \mathrm{~g} / \mathrm{L}$ of GAC & & & 40.0 & approx. 3.4 & to 0.6 & \\
\hline control & \multirow[t]{2}{*}{-} & \multirow{2}{*}{$\begin{array}{l}\min .800 \\
\max .2000\end{array}$} & 47.9 & 5.45 & from 0.6 to 4.0 & \multirow{2}{*}[22]{} \\
\hline with $3.0 \mathrm{~g} / \mathrm{L}$ of zeolite & & & 34.9 & 7.36 & from 1.0 to 5.0 & \\
\hline control & \multirow{2}{*}{1.5} & \multirow{2}{*}{503} & 70.0 & 3.50 & lack of granules & \multirow{2}{*}[10]{} \\
\hline with $1.0 \mathrm{~g} / \mathrm{L}$ of GAC & & & 26.0 & 9.08 & 0.44 & \\
\hline control & \multirow{2}{*}{4.0} & \multirow{2}{*}{$\begin{array}{l}\min .800 \\
\max .1000\end{array}$} & 73.0 & 4.92 & approx. 0.2 & \multirow{2}{*}[25]{} \\
\hline with $1.0 \mathrm{~g} / \mathrm{L}$ of SSM & & & 51.0 & 8.62 & approx. 0.4 & \\
\hline $\begin{array}{c}\text { with } 20.0 \mathrm{~g} / \mathrm{L} \text { of basalt } \\
\text { (SBAR) }\end{array}$ & \multirow[t]{2}{*}{$3.0-4.0$} & \multirow[t]{2}{*}{-} & to 32.0 & 11.23 & from 0.3 to 3.7 & \multirow{2}{*}[20]{} \\
\hline $\begin{array}{c}\text { with } 20.0 \mathrm{~g} / \mathrm{L} \text { of basalt } \\
\text { (SBBR) }\end{array}$ & & & to 28.0 & 12.78 & from 0.3 to 4.0 & \\
\hline $\begin{array}{l}\text { control }\left(35 \mathrm{~cm}^{3} \text { of }\right. \\
\text { anaerobic granules) }\end{array}$ & \multirow[t]{2}{*}{$2.5-30.0$} & \multirow[t]{2}{*}{600} & 19.0 & approx. 15 & from 0.3 to 4.0 & \multirow[t]{2}{*}[21,31]{} \\
\hline with $20.0 \mathrm{~g} / \mathrm{L}$ of BSC & & & 14.0 & approx. 10 & from 0.5 to 2.0 & \\
\hline \multirow{2}{*}{$\begin{array}{c}\text { with } 3.0 \mathrm{~g} / \mathrm{L} \text { of } \\
\text { powdered ceramsite }\end{array}$} & 2.1 & $862.8 \pm 31.0$ & 30.1 & $4.37^{* *}$ & to 0.96 & \multirow{2}{*}[11]{} \\
\hline & 1.0 & $408.9 \pm 12.9$ & 36.9 & $3.03^{* *}$ & to 0.29 & \\
\hline
\end{tabular}

PAC—powdered activated carbon; GAC—granular activated carbon; SMM—sewage sludge micropowder; BSC—bivalve shell carrier; SBAR—sequencing batch airlift reactor; SBBR—sequencing batch bubble reactor. * breakup of granules. ${ }^{* *}$ MLVSS $(\mathrm{g} / \mathrm{L})$.

Starting on the nineteenth day of the experiment, the $\mathrm{SVI}_{5} / \mathrm{SVI}_{30}$ ratio was observed to be significantly lower in the reactors with powdered materials. The $\mathrm{SVI}_{5} / \mathrm{SVI}_{30}$ values of $\mathrm{R} 2$ and $\mathrm{R} 3$ indicate that the addition of PK and PL could clearly improve both the sludge settling capacity and its compressibility. Marked correlations were noted between a lower $\mathrm{SVI}_{5} / \mathrm{SVI}_{30}$ value and increased floc size (early in the experiment) and the growth of granules (later in the experiment). In the reactors with PK and PL, data dependency was found to be statistically significant $(p<\alpha, p=0.0105$ for R2, and $p=0.0221$ for R3) (Figure 3a). 


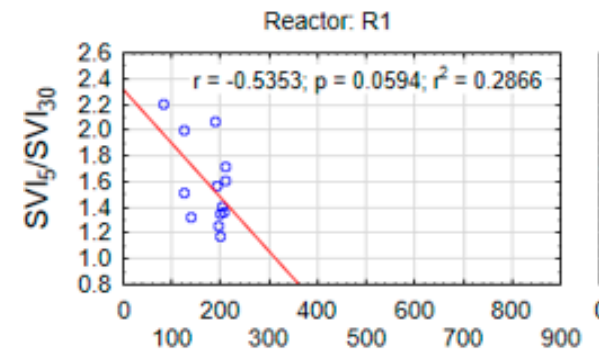

a)

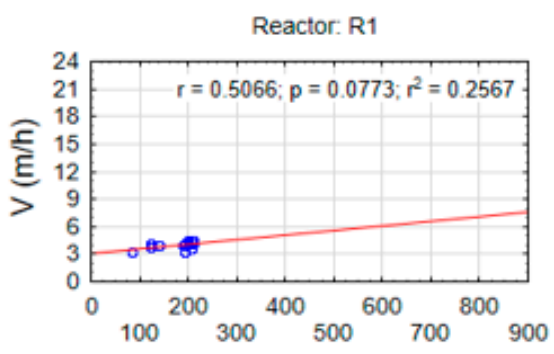

b)

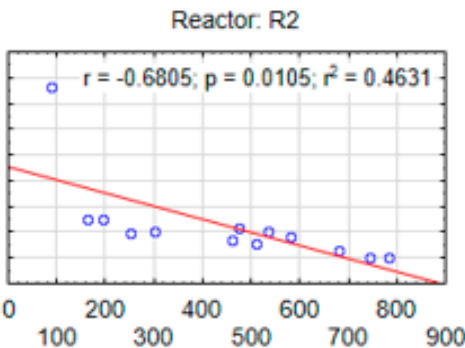

Diameter $(\mu \mathrm{m})$
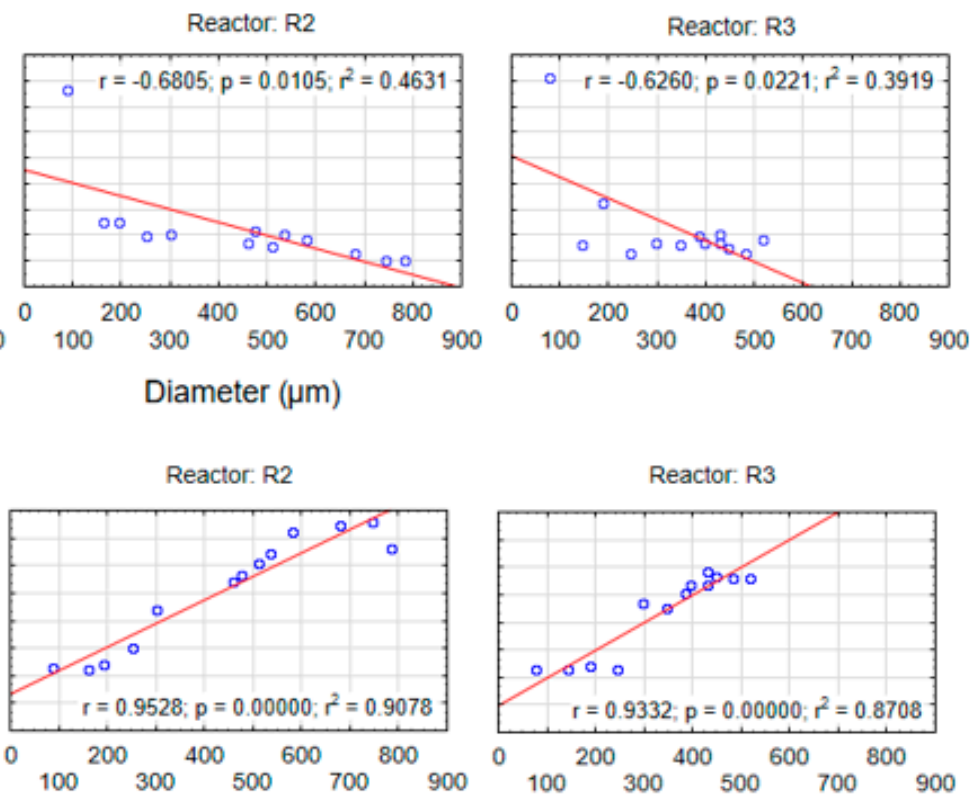

Diameter $(\mu \mathrm{m})$

Figure 3. Scatter graphs showing the relationships between the granule diameter and $\mathrm{SVI}_{5} / \mathrm{SVI}_{30}(\mathbf{a})$ and settling velocity $(\mathbf{b})$.

The application of mineral materials increased the settling velocity. First, in the early stages of the experiment, the materials acted as ballast for sludge flocs, increasing their weight. This affected the sedimentation properties of the biomass and also reduced the rate of biomass elution from reactors R2 and R3, ensuring that biogranulation occurred. Higher settling velocities were observed in reactors R2 and R3 (Figure 3b), and the values resembled those given in the literature. Li et al. [42] showed that, in a reactor to which GAC $(0.5 \mathrm{~g} / \mathrm{L})$ had been added, the settling velocity of the biomass was $18.5 \mathrm{~m} / \mathrm{h}$. However, in a reactor to which powdered activated carbon (PAC) $(0.5 \mathrm{~g} / \mathrm{L})$ was added, this value was $13.7 \mathrm{~m} / \mathrm{h}$. By contrast, Wei et al. [23] reported higher settling velocities of up to $25 \mathrm{~m} / \mathrm{h}$, as well as a relationship between the increased velocity and increased density and diameter of the granules. These values are much higher than the settling velocity of ordinary activated sludge, which is $1-2 \mathrm{~m} / \mathrm{h}$ [21]. The relationship between the settling velocity and granule diameter was statistically significant in the reactors with powdered ceramsite and limestone ( $p<\alpha, p=0.0000$ for R2, and $p=0.0000$ for R3) (Figure 3b).

\subsection{Formation of Aerobic Granules}

Fourteen days after the acclimation period ended, the cumulative volume percentages of granules with diameters exceeding $200 \mu \mathrm{m}$ were $9.38 \%, 38 \%$, and $31 \%$ in reactors $\mathrm{R} 1, \mathrm{R} 2$, and R3, respectively. This result indicated that sludge flocs were still the dominant form of biomass in both reactors supplemented with powdered mineral. The mean aggregate size measured on day 26 had increased from 76.4 to $246.0 \mu \mathrm{m}$ (R3) and from 89.3 to $251.9 \mu \mathrm{m}$ (R2). After 54 days, complete granulation was observed (according to the definition [19], when particles smaller than $200 \mu \mathrm{m}$ constitute less than 10\% of biomass, full granulation is said), and the mean aggregate size was $511.3 \mu \mathrm{m}$ in R2 and $396.0 \mu \mathrm{m}$ in R3. No apparent increase in granule size was observed in R1. After 89 days of GSBR operation, the mean sizes of the aggregates were 200.2, 783.1, and $430.0 \mu \mathrm{m}$ in R1, R2, and R3, respectively (Figure 4a). The biogranulation process itself with the addition of these two materials, among others, is discussed in more detail in the article by Czarnota et al. [33], which presents the impact of different powdered mineral materials on selected properties of aerobic granular sludge. Table 5 lists the average sizes of granules reported in previous studies of reactors in which powdered materials were applied. 
An extensive discussion of the results of own research with the literature data in this area is detailed in the publication by Czarnota et al. [33].
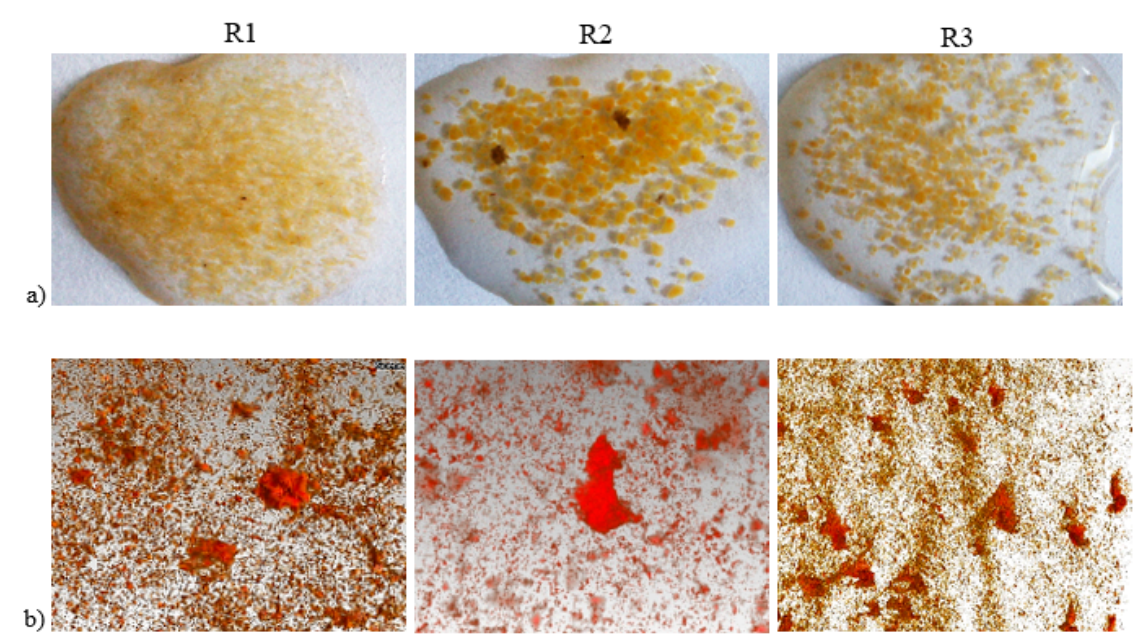

Figure 4. Characteristic biomass: photographs (a) and X-ray tomography images (b) of granules after 89 days of granulation.

The more stable growth of granules in reactor R2, as well as the presence of larger aggregates, resulted from the application of ceramsite. Under a microscope, ceramsite particles were clearly visible within structures formed by sludge flocs and granules (regular suspending together with the biomass). To a lesser extent, the same was also observed for the powdered limestone. In addition, it was possible to observe the formation of granules containing microparticles of ceramsite. More information on these issues may be found in the previous publication [33] of the authors. Furthermore, after 68 days, the average size of granules in reactor R3 was decreasing, which is consistent with results reported by Wei et al. [23]. In a reactor with added PAC, on the fiftieth day of testing, the average granule size was $364.0 \mu \mathrm{m}$, and the percentage of aggregates above $200.0 \mu \mathrm{m}$ in diameter was $67.1 \%$. In the following days, the authors observed an increase in granule diameter compared with that on the fiftieth day. However, the average granule size decreased over time (from $596.0 \mu \mathrm{m}$ on day 90 to $485.0 \mu \mathrm{m}$ on day 113). The percentage of aggregates with sizes above $200.0 \mu \mathrm{m}$ increased to a maximum of $79.6 \%$. In the control reactor, 50 days into the research, the granules began to disintegrate. The authors summarized the research by saying that the application of PAC afforded a stable biogranulation process, and the obtained granules showed greater stability and more favorable sedimentation properties.

Statistical analysis revealed a highly significant relationship between a slight increase in OLR and granule growth ( $p<\alpha, p=0.0010$ for R1, $p=0.0023$ for R2, and $p=0.0011$ for R3) (Figure 5). Even though the use of the lowest optimal OLR, with an average value of $2.55 \mathrm{~g} C O D /(L \cdot d)$, affected the volume of the reactor, biogranulation occurred slowly in the control system. The powdered materials can thus be said to have played an important role in the biogranulation process.

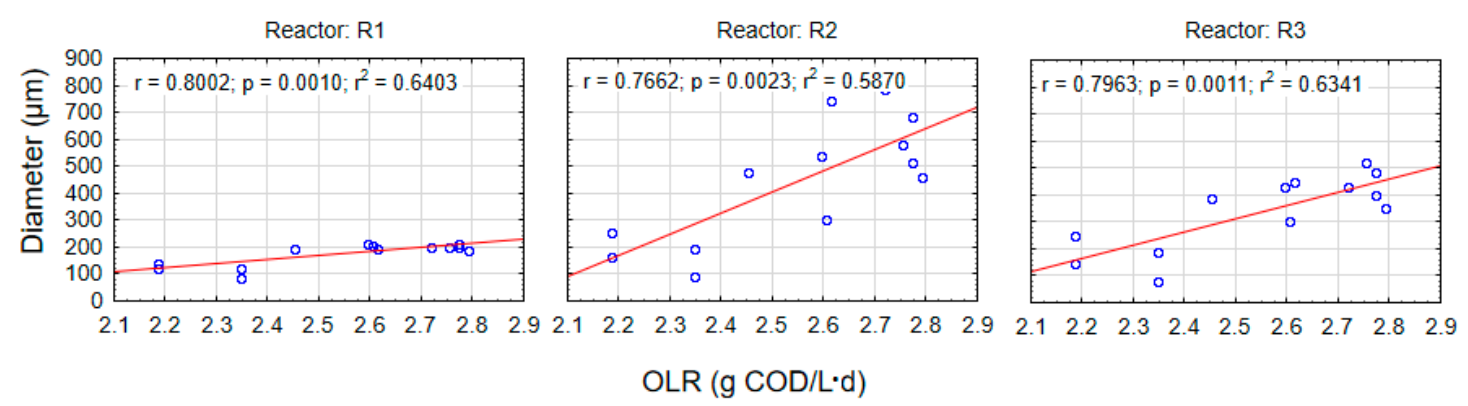

Figure 5. Scatter graph showing the relationship between granule diameter and OLR. 


\subsection{Structural Characteristics and Bioactivity of Granular Sludge}

The computed tomography results revealed significant differences between the surfaces of granules from different reactors. In the control reactor, the biomass had a fluffy surface with filamentous microorganisms. These bacteria dominated the granules and contributed to loosening of their structure [43]. By contrast, the granules from the reactors with added powdered materials exhibited nonfibrous and smoother surfaces. The surfaces of the granules from reactors R2 and R3 had visible corrugations, most probably because of the greater porosity of these aggregates (Figure $4 \mathrm{~b}$ ).

The application of powdered ceramsite and limestone prevented biomass from being washed out of the reactors and thus limited the development of filamentous bacteria [33]. The SEM analysis indicates that these bacteria formed a framework around the granules. However, in reactor R1, in which the number of filamentous microorganisms was greatest, they not only formed a framework around the granules, but also filled in the spaces in that framework, which affected the qualitative composition of the biocoenosis in this reactor. By contrast, open spaces were present in the framework of granules in the reactors with powdered materials. Their presence provided for the existence of other microorganisms and filled voids inside the granules.

Ca-rich granules have higher mechanical strength but lower bioactivity, so the calcium ion content of aerobic granules is one of the factors determining their bioactivity. The granulation time and stimulation of cell-to-cell aggregation can be reduced by calcium-induced dehydration of bacterial cell surfaces [43-45]. In the present study, the concentration of calcium ions in the raw wastewater was $0.27 \mathrm{mmol} \mathrm{Ca} / \mathrm{L}$. Additionally, in the first cycle of reactor operation (under assumed hydraulic conditions), $0.127 \mathrm{mmol} \mathrm{Ca} / \mathrm{L}$ from the powdered ceramsite or $0.674 \mathrm{mmol} \mathrm{Ca} / \mathrm{L}$ from the powdered limestone was introduced. The total amount of calcium cations was less than $1.0 \mathrm{mmol} \mathrm{Ca} / \mathrm{L}$ throughout the experiment. Ren et al. [35] showed that when granules grew on wastewater with a calcium concentration of $1.0 \mathrm{mmol} \mathrm{Ca} / \mathrm{L}$, the SOUR was $9.55 \pm 0.11 \mathrm{mg} \mathrm{O}_{2} /(\mathrm{g}$ VSS$\cdot \mathrm{h})$, and when the $\mathrm{Ca}^{2+}$ concentration was $0.5 \mathrm{mmol} \mathrm{Ca} / \mathrm{L}$, the SOUR was $22.26 \pm 0.25 \mathrm{mg} \mathrm{O}_{2} /(\mathrm{g}$ VSS$\cdot h)$. The rate of oxygen uptake by biomass was highest in R1 and ranged from 20.42 to $28.57 \mathrm{mg} \mathrm{O}_{2} /(\mathrm{g}$ VSS.h), but on the eighty-second day of the study, the rate decreased significantly to $7.85 \mathrm{mg} \mathrm{O}_{2} /(\mathrm{g}$ VSS$\cdot h)$. These results indicate insufficient biomass content in the reactor and may also suggest accumulation of compounds (e.g., nitrates) with toxic or inhibitory effects on certain groups of microorganisms in the final stage of the experiment. The SOUR was 9.16-14.96 $\mathrm{mg} \mathrm{O}_{2} /\left(\mathrm{g}\right.$ VSS.h) in $\mathrm{R} 2$ and $6.81-12.65 \mathrm{mg} \mathrm{O}_{2} /(\mathrm{g} \mathrm{VSS} \cdot \mathrm{h}$ ) in R3. The lower SOUR values in these reactors result mainly from higher biomass concentrations.

\subsection{Carbon, Nitrogen, and Phosphorus Removal}

The influent COD concentration of the three reactors was $717.1 \pm 62.6 \mathrm{mg} \mathrm{O} / \mathrm{L}$, and the OLR was approximately $2.55 \mathrm{~g} \mathrm{COD} /(\mathrm{L} \cdot \mathrm{d})$. The COD values in the effluent of R1, R2, and R3 ranged from 60.8 to $286.4 \mathrm{mg} \mathrm{O}_{2} / \mathrm{L}, 34.4$ to $160.0 \mathrm{mg} \mathrm{O}_{2} / \mathrm{L}$, and 46.4 to $195.2 \mathrm{mg} \mathrm{O}_{2} / \mathrm{L}$, respectively (Figure $6 \mathrm{a}$ ). It was possible to remove $77.4 \pm 11.1 \%$ of the organic compounds in R1, $85.4 \pm 5.4 \%$ in $\mathrm{R} 2$, and $82.0 \pm 6.1 \%$ in R3 (Figure $6 \mathrm{~b}$ ). The reactors with powdered materials exhibited better COD removal. The food-to-microorganism (F/M) ratio was $0.757-1.137 \mathrm{~g}$ COD/(g VSS·d) in the control reactor, $0.382-0.676 \mathrm{~g} \mathrm{COD} /(\mathrm{g}$ VSS·d) in R2, and 0.302-1.183 g COD/(g VSS·d) in R3. Wu et al. [46] studied the optimal F/M ratio for granule stabilization. They found that F/M ratios between 0.4 and $0.5 \mathrm{~g}$ $\mathrm{COD} /(\mathrm{g}$ VSS$\cdot \mathrm{d}$ ) were associated with greater microbial diversity and higher pollutant removal efficiency.

Kruskal-Wallis testing of many independent samples did not reveal statistically significant differences in COD removal between the reactors $(p>\alpha, p=0.0534)$. However, comparison between the value of the control reactor and that of each reactor with a powdered material, and the use of the Mann-Whitney $U$ test for two independent samples, showed statistically significant differences in COD removal between $\mathrm{R} 1$ and $\mathrm{R} 2(p<\alpha, p=0.0240)$. The values obtained in $\mathrm{R} 2$ were close to those obtained by Minh [20], who used basalt to support a reactor operating at an OLR of $3.0 \mathrm{~g} \mathrm{COD} /(\mathrm{L} \cdot \mathrm{d})$ (78.0-97.0\%). The values were also higher than those reported by Wei et al. [23], who applied PAC to a reactor operating at an OLR of $2.10 \mathrm{~g} \mathrm{COD} /(\mathrm{L} \cdot \mathrm{d})$ (approximately $65.0 \%$ ). 

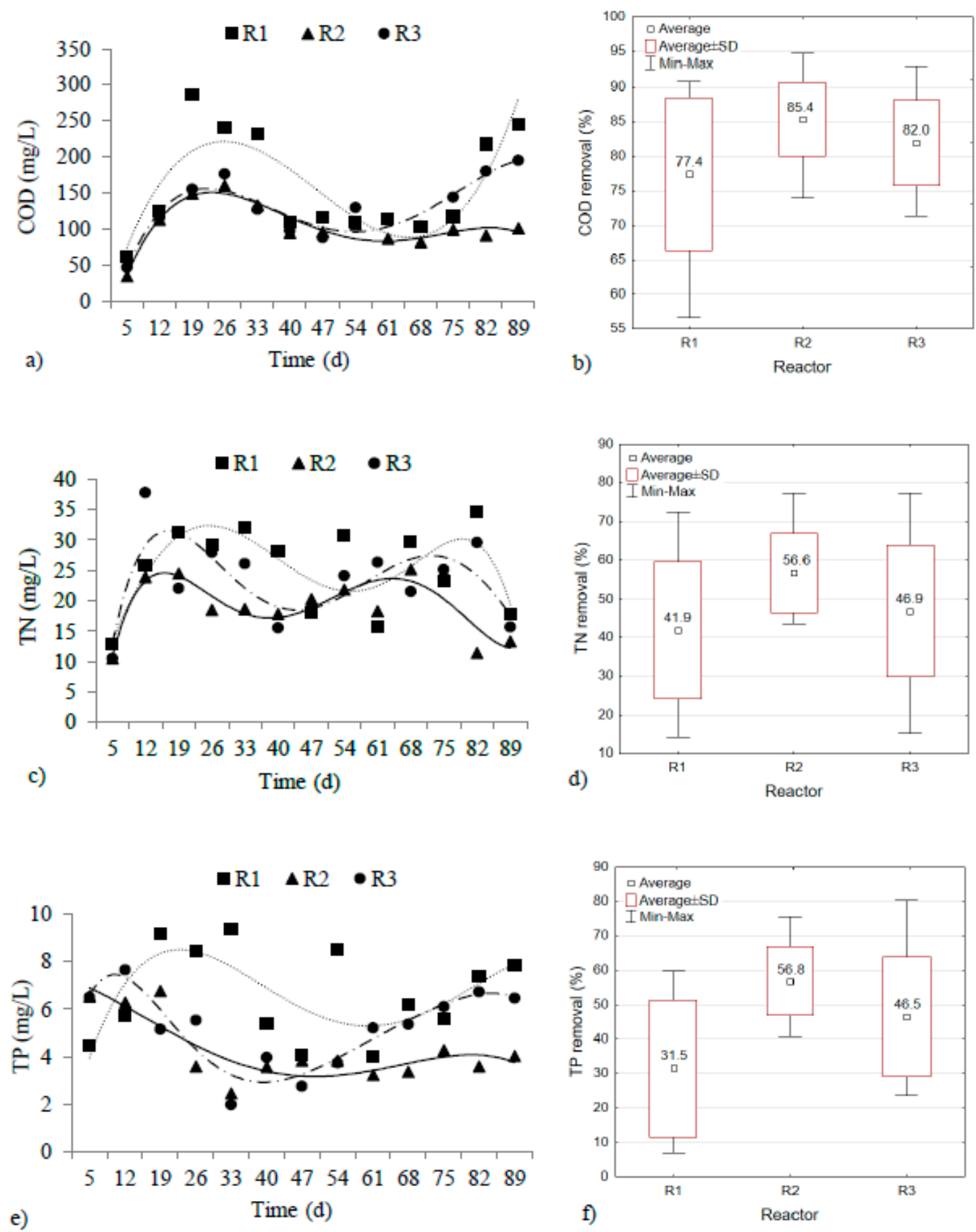

Figure 6. Reactor performance: changes in $\operatorname{COD~(a),~TN~(c),~TP~(e)~in~effluent~and~average~values~of~}$ $\mathrm{COD}(\mathbf{b}), \mathrm{TN}(\mathbf{d})$, and TP $(\mathbf{f})$ removal.

Organic compounds were removed during the feeding and reaction phases of the wastewater treatment cycle. In the reactors with powdered materials, the dynamics of COD removal were higher than those in the control reactor. In the settling, decantation, and idle phases, a slight decrease in the efficiency of organic compound removal was observed, most probably as a result of the release of EPS to the wastewater. Kończak and Miksch [47] studied the dynamics of organic compound removal, as well as changes in the protein and polysaccharide contents during the cycle. They found that the COD concentrations decreased in the aeration phase, during which the extracellular protein content increased and the polysaccharide content remained constant. However, under a prolonged 
substrate shortage, previously consumed microorganisms accumulated cellular proteins, some of which were released into the supernatant, causing secondary contamination of the treated wastewater with organic substances.

The influent TN concentration of the three GSBRs was $44.0 \pm 3.0 \mathrm{mg} \mathrm{N} / \mathrm{L}$, and the TN loading rate of the reactors was $0.157 \pm 0.011 \mathrm{~g} \mathrm{~N} /(\mathrm{L} \cdot \mathrm{d})$. The $\mathrm{TN}$ values in the effluent of $\mathrm{R} 1, \mathrm{R} 2$, and R3 were 12.9-34.6 mg N/L, 10.6-25.2 mg N/L, and 10.5-37.8 mg N/L, respectively (Figure 6c). The average efficiencies of TN removal were highest in reactor R2 (56.6 $\pm 10.2 \%)$ compared with R1 and R3 $(41.9 \pm 17.7 \%$ and $46.9 \pm 17.1 \%$, respectively) (Figure $6 \mathrm{~d})$. Kruskal-Wallis testing of many independent samples did not reveal statistically significant differences in TN removal between the reactors $(p>\alpha$, $p=0.0943)$. However, a comparison of the control reactor and each reactor with a powdered material, and application of the Mann-Whitney $U$ test to two independent samples, showed statistically significant differences in TN removal between R1 and R2 $(p<\alpha, p=0.0402)$. The values obtained in $\mathrm{R} 2$ are similar to those published by Tao et al. [26] (60\% for TN). In turn, Zhou et al. [10] investigated a reactor with GAC having a $0.2 \mathrm{~mm}$ particle size and obtained a TN removal efficiency of $72.5 \%$. In the reactor with powdered ceramsite, a very high efficiency of $\mathrm{NH}_{4}{ }^{+}-\mathrm{N}$ removal was observed $(95.1 \pm 12.8 \%)$, whereas approximately $78.7 \pm 17.0 \%$ and $86.6 \pm 22.4 \%$ of $\mathrm{NH}_{4}{ }^{+}-\mathrm{N}$ was eliminated in reactors $\mathrm{R} 1$ and $\mathrm{R} 3$.

In wastewater treatment systems based on aerobic granular sludge, various mechanisms may be used to remove nitrogen compounds (e.g., assimilation, together with anaerobic ammonium oxidation or simultaneous nitrification and denitrification) [48]. In our research, the removal of nitrogen compounds by simultaneous nitrification/denitrification (SND) was not precluded. The effectiveness of this process in the reactors was evaluated in accordance with the guidelines of Wei et al. [22]. The SND efficiencies of R1, R2, and R3 were $75.7 \pm 20.5 \%, 77.4 \pm 7.1 \%$, and $76.8 \pm 6.4 \%$, respectively. Note that the values for R1 are unreliable because the overall depletion of ammonium-nitrogen, i.e., the sum of nitrates and nitrites present in the reactor, was not constantly observed. The obtained SND efficiencies are comparable to the literature data. Wei et al. [22] reported that for $\mathrm{C} / \mathrm{N}=6$, the SND efficiency was $94.6 \%$ and $92 \%$ in a reactor with zeolite and a control reactor, respectively. However, when $C / N=10$, the efficiency of this process was lower, at $72.0 \%$ and $55.0 \%$, respectively. Adoption of a $\mathrm{C} / \mathrm{N}$ ratio of 16 in these studies could have affected the TN removal. According to the information provided by literature, it is necessary to develop mature granules for effective denitrification [48]. Moreover, small size of granules may significantly reduce the anoxic zones during the aeration phase [3]. Our own research did not demonstrate that increasing the granulate diameter had any effect on the efficiency of the SND process or the removal of nitrogen compounds.

The influent TP concentration in the three reactors was $9.73 \pm 1.05 \mathrm{mg} \mathrm{P} / \mathrm{L}$, and the TP loading rate of the GSBRs was $0.035 \pm 0.004 \mathrm{~g} \mathrm{P} /(\mathrm{L} \cdot \mathrm{d})$. The TP values in the effluent of reactors $\mathrm{R} 1, \mathrm{R} 2$, and $\mathrm{R} 3$ were 4.03-9.36 mg P/L, 2.46-6.76 mg P/L, and 1.98-7.65 mg P/L, respectively (Figure 6e). The lowest $\mathrm{TP}$ values were recorded in the outflow from R2. In R3, starting on day 40 of the experiment, the TP concentration in the treated wastewater increased. The average TP removal efficiencies of R1, R2, and R3 were thus $31.5 \pm 19.8 \%, 56.8 \pm 9.9 \%$, and $46.5 \pm 17.5 \%$, respectively (Figure $6 f$ ). Statistical analysis revealed significant differences in TP removal between the reactors $(p<\alpha, p=0.0032)$.

To date, most papers on support of AGS technologies using powdered materials have ignored the removal of phosphorus compounds. He et al. [4], who used yellow earth to support a reactor operating without an anaerobic phase, obtained TP removal efficiencies of $17-46 \%$. The efficiency of TP removal reported here for reactors with added powdered materials are greater than those presented by He et al. [4]. Our research also did not consider a separate anaerobic phase in the reactor cycle. Tao et al. [26], who used GAC to support a reactor, obtained higher TP removal rates (15-99\%). However, they did add a 99-min anaerobic phase to the reactor operating cycle. Analysis of the dynamics of $\mathrm{PO}_{4}{ }^{3-}-\mathrm{P}$ removal in our research showed a lack of phosphate release, indicating a lack of effective biological dephosphatation, despite the favorable C/P ratio adopted for this process. In view of the above, it can be concluded that the removal of phosphorus compounds could have 
occurred by precipitation of phosphorus as inorganic phosphate such as $\mathrm{Ca}_{3}\left(\mathrm{PO}_{4}\right)_{2}$ and $\mathrm{MgHPO}$. Such a mechanism for phosphorus removal in AGS technology has been indicated by, among others, Filali et al. [49] and Manas et al. [50]. There was a high negative correlation between the TP removal and TP loading rate of biomass in the reactors supported by powdered materials.

\section{Conclusions}

The development and maturation of aerobic granules at a low OLR requires a long time period; however, the addition of mineral particles might improve the biogranulation process. This study revealed that powdered ceramsite or limestone affected the formation of granules in reactors under the specified operating parameters $(251.9 \mu \mathrm{m}<\mathrm{d}$ in $\mathrm{R} 2<783.1 \mu \mathrm{m}$ and $246.0 \mu \mathrm{m}<\mathrm{d}$ in $\mathrm{R} 3<518.9 \mu \mathrm{m})$, whereas in the control reactor, complete granulation was not achieved $(124.0 \mu \mathrm{m}<\mathrm{d}$ in $\mathrm{R} 1<210.0 \mu \mathrm{m})$. The use of powdered materials was found to significantly enhance the sedimentation properties of biomass during biogranulation, ensuring a lower rate of biomass elution and a higher biomass concentration in the reactors. Moreover, in R2 and R3 reactors, relationships between the granule diameter and $\mathrm{SVI}_{5} / \mathrm{SVI}_{30}$ or settling velocity were statistically significant $(p<\alpha, p=0.0105$ for $\mathrm{R} 2$ and $p=0.0221$ for R3 or $p=0.0000$ for R2 and $p=0.0000$ for R3). The most efficient wastewater treatment (COD: $85.4 \pm 5.4 \%$, TN: $56.6 \pm 10.2 \%$, and TP: $56.8 \pm 9.9 \%$ ) and strongest effect on the sludge sedimentation properties (resulting in the highest value of MLVSS: $4.12 \mathrm{~g} / \mathrm{L}$ ) were obtained using powdered ceramsite. Moreover, this material acted not only as ballast for the sludge flocs making up the seed sludge, but also as microcarriers of granule-forming biomass. The results showed that, under the specified operating parameters for the control reactor, granule formation could not occur.

An important issue in the assessment of biological wastewater treatment, especially in new technologies, is the accurate recognition of the individual pollution removal processes. Therefore, the next stage of research may be investigation of nitrification, denitrification, and dephosphatation processes, based on profile tests including the determination of $\mathrm{COD}, \mathrm{NH}_{4}{ }^{+}-\mathrm{N}, \mathrm{NO}_{2}{ }^{-}-\mathrm{N}, \mathrm{NO}_{3}{ }^{-}-\mathrm{N}$, and $\mathrm{PO}_{4}{ }^{3-}-\mathrm{P}$, in individual phases of the GSBR cycle with the addition of powdered material.

Author Contributions: Conceptualization, J.C. and A.M.; methodology, J.C. and A.M.; investigation, J.C. and A.P.; writing-original draft preparation, J.C. and A.M.; writing-review and editing, formal analysis, G.E.; supervision, A.M. and J.A.T. All authors have read and agreed to the published version of the manuscript.

Funding: This work was partly financially supported within the statutory research of particular scientific units under subvention for a science program.

Acknowledgments: To obtain the results presented in Figure $4 \mathrm{~b}$, the research apparatus of the Interuniversity Laboratory in Stalowa Wola was used; the apparatus was purchased as part of the project "Establishment of scientific research in Intercollegiate Laboratory in Stalowa Wola" under the Operational Program Development of Eastern Poland 2007-2013, Priority Axis I Modern Economy, Action I.3 Supporting Innovation in accordance with Agreement No. POPW.01.03.00-18-016/12-00.

Conflicts of Interest: The authors declare no conflict of interest.

\section{References}

1. Guo, N.; Zhang, J.; Xie, H.-J.; Tan, L.-R.; Luo, J.-N.; Tao, Z.-Y.; Wang, S.-G. Effects of the Food-to-Microorganism (F/M) Ratio on $\mathrm{N}_{2} \mathrm{O}$ Emissions in Aerobic Granular Sludge Sequencing Batch Airlift Reactors. Water 2017, 9, 477. [CrossRef]

2. Jafari Kang, A.; Yuan, Q. Long-term stability and nutrient removal efficiency of aerobic granules at low organic loads. Biores. Technol. 2017, 234, 336-342. [CrossRef]

3. Zou, J.; Pan, J.; Wu, S.; Qian, M.; He, Z.; Wang, B.; Li, J. Rapid control of activated sludge bulking and simultaneous acceleration of aerobic granulation by adding intact aerobic granular sludge. Sci. Total Environ. 2019, 674, 105-113. [CrossRef]

4. He, Q.L.; Zhang, S.L.; Zou, Z.C.; Wang, H.Y. Enhanced formation of aerobic granular sludge with yellow earth as nucleating agent in a sequencing batch reactor. IOP Conf. Ser. Earth Environ. Sci. 2016, 39, 1-10. [CrossRef] 
5. Bengtssona, S.; de Bloisc, M.; Wilen, B.-M.; Gustavssond, D. Treatment of municipal wastewater with aerobic granular sludge. Crit. Rev. Environ. Sci. Technol. 2018, 48, 119-166. [CrossRef]

6. Nancharaiah, Y.V.; Kiran Kumar Reddy, G. Aerobic granular sludge technology: Mechanisms of granulation and biotechnological applications. Biores. Technol. 2018, 247, 1128-1143. [CrossRef]

7. Tay, J.H.; Pan, S.; He, Y.; Tay, S.T.L. Effect of organic loading rate on aerobic granulation. I: Reactor performance. J. Environ. Eng. 2004, 130, 1094-1101. [CrossRef]

8. De Kreuk, M.K.; Kishida, N.; Tsuneda, S.; van Loosdrecht, M.C.M. Behavior of polymeric substrates in an aerobic granular sludge system. Wat. Res. 2010, 44, 5929-5938. [CrossRef]

9. Sheng, G.P.; Li, A.J.; Li, X.Y.; Yu, H.Q. Effects of seed sludge properties and selective biomass discharge on aerobic sludge granulation. Chem. Eng. J. 2010, 160, 108-114. [CrossRef]

10. Zhou, J.-H.; Zhao, H.; Hu, M.; Yu, H.-T.; Xu, X.-Y.; Vidonish, J.; Alvarez, P.J.J.; Zhu, L. Granular activated carbon as nucleating agent for aerobic sludge granulation: Effect of GAC size on velocity field differences (GAC versus flocs) and aggregation behavior. Biores. Technol. 2015, 198, 358-363. [CrossRef]

11. Czarnota, J.; Masłon, A. Biogranulation and physical properties of aerobic granules in reactors at low organic loading rate and with powdered ceramsite added. J. Ecol. Eng. 2019, 20, 202-210. [CrossRef]

12. Sguanci, S.; Lubello, C.; Caffaz, S.; Lotti, T. Long-term stability of aerobic granular sludge for the treatment of very low-strength real domestic wastewater. J. Clean. Prod. 2019, 222, 882-890. [CrossRef]

13. Kim, I.S.; Kim, S.M.; Jang, A. Characterization of aerobic granules by microbial density at different COD loading rates. Biores. Technol. 2008, 99, 18-25. [CrossRef]

14. Sarma, S.J.; Tay, J.H.; Chu, A. Finding Knowledge Gaps in Aerobic Granulation Technology. Trends Biotechnol. 2017, 35, 66-78. [CrossRef]

15. Czarnota, J.; Masłoń, A.; Zdeb, M. Powdered keramsite as unconventional method of AGS technology support in GSBR reactor with minimum-optimum OLR. E3S Web Conf. 2018, 44, 00024. [CrossRef]

16. De Kreuk, M.K.; van Loosdrecht, M.C. Formation of aerobic granules with domestic sewage. J. Environ. Eng. 2006, 132, 694-697. [CrossRef]

17. Val del Río, A.; Morales, N.; Figueroa, M.; Mosquera-Corral, A.; Campos, J.L.; Méndez, R. Effect of coagulant-flocculant reagents on aerobic granular biomass. J. Chem. Technol. Biotechnol. 2012, 87, 908-913. [CrossRef]

18. Pijuan, M.; Werner, U.; Yuan, Z.G. Reducing the startup time of aerobic granular sludge reactors through seeding floccular sludge with crushed aerobic granules. Water Res. 2011, 45, 5075-5083. [CrossRef]

19. Verawaty, M.; Pijuan, M.; Yuan, Z.; Bond, P.L. Determining the mechanisms for aerobic granulation from mixed seed of floccular and crushed granules in activated sludge wastewater treatment. Water Res. 2012, 46, 761-771. [CrossRef]

20. Minh, N.D. Treatment of High-Strength Organic Wastewater Using an Aerobic Granular System with Baffed Membrane Bioreactor AIT Thesis. Master's Thesis, Asian Institute of Technology, Bangkok, Thailand, 2006; pp. 1-119.

21. Thanh, B.X.; Visvanathan, C.; Aim, R.B. Characterization of aerobic granular sludge at various organic loading rates. Process Biochem. 2009, 44, 242-245. [CrossRef]

22. Wei, D.; Xue, X.; Chen, S.; Zhang, Y.; Yan, L.; Wei, Q.; Du, B. Enhanced aerobic granulation and nitrogen removal by the addition of zeolite powder in a sequencing batch reactor. Appl. Microbiol. Biotechnol. 2013, 97, 9235-9243. [CrossRef]

23. Wei, Y.; Ji, M.; Li, G.; Qin, F. Powdered Activated Carbon (PAC) Addition for Enhancement of Aerobically Grown Microbial Granules Treating Landfill Leachate. In Proceedings of the 2010 the 2nd Conference on Environmental Science and Information Application Technology, Wuhan, China, 17-18 July 2010; pp. 805-808. [CrossRef]

24. Li, A.J.; Li, X.Y.; Yu, H.Q. Granular activated carbon for aerobic sludge granulation in a bioreactor with a low-strength wastewater influent. Sep. Purif. Technol. 2011, 80, 276-283. [CrossRef]

25. Li, J.; Liu, J.; Wang, D.; Chen, T.; Ma, T.; Wang, Z.; Zhuo, W. Accelerating Aerobic Sludge Granulation by Adding Dry Sewage Sludge Micropowder in Sequencing Batch Reactors. Int. J. Environ. Res. Public Health 2015, 12, 10056-10065. [CrossRef]

26. Tao, J.; Qin, L.; Liu, X.; Li, B.; Chen, J.; You, J.; Shen, Y.; Chen, H. Effect of granular activated carbon on the aerobic granulation of sludge and its mechanism. Biores. Technol. 2017, 236, 60-67. [CrossRef] 
27. Zhang, D.; Li, W.; Hou, C.; Shen, J.; Jiang, X.; Sun, X.; Li, J.; Han, W.; Wang, L.; Liu, X. Aerobic granulation accelerated by biochar for the treatment of refractory wastewater. Chem. Eng. J. 2017, 314, 88-97. [CrossRef]

28. Liang, Z.; Tu, Q.; Su, X.; Yang, X.; Chen, J.; Chen, Y.; Li, H.; Liu, C.; He, Q. Formation, Extracellular Polymeric Substances, and Structural Stability of Aerobic Granules Enhanced by Granular Activated Carbon. Environ. Sci. Pollut. Res. 2019, 26, 6123-6132. [CrossRef]

29. Zhang, Y.; Dong, X.; Nuramkhaan, M.; Lei, Z.; Shimizu, K.; Zhang, Z.; Adachi, Y.; Lee, D.-J.; Tay, J.-H. Rapid granulation of aerobic granular sludge: A mini review on operation strategies and comparative analysis. Biores. Technol. Rep. 2019, 7, 1-12. [CrossRef]

30. Lin, H.; Ma, R.; Hu, Y.; Lin, J.; Sun, S.; Jiang, J.; Li, T.; Liao, Q.; Luo, J. Reviewing bottlenecks in aerobic granular sludge technology: Slow granulation and low granular stability. Environ. Pollut. 2020, 263, 1-11. [CrossRef]

31. Thanh, B.X.; Visvanathan, C.; Aim, R.B. Fouling characterization in aerobic granulation coupled baffled membrane bioreactor. J. Membrane Sci. 2008, 318, 334-339. [CrossRef]

32. Thanh, B.X. Aerobic Granulation Coupled Membrane Bioreactor. AIT Thesis No. EV-05-5. Master's Thesis, Asian Institute of Technology, Bangkok, Thailand, 2005; pp. 1-157.

33. Czarnota, J.; Masłoń, A.; Zdeb, M.; Łagód, G. The impact of different powdered mineral materials on selected properties of aerobic granular sludge. Molecules 2020, 25, 386. [CrossRef]

34. Czarnota, J.; Tomaszek, J.A.; Masłon, A. The use of powdered materials in the technology of aerobic granular sludge. Gas Water Sanit. Eng. 2016, 11, 411-417. (In Polish) [CrossRef]

35. Ren, T.T.; Liu, L.; Sheng, G.P.; Liu, X.W.; Yu, H.Q. Calcium spatial distribution in aerobic granules and its effects on granule structure, strength and bioactivity. Water Res. 2008, 42, 3343-3352. [CrossRef]

36. Kończak, B.; Miksch, K. Effect of $\mathrm{Ca}^{2+}, \mathrm{Mg}^{2+}$ i Fe ${ }^{3+}$ cations on formation of aerobic granular biomass. Przem. Chem. 2011, 90, 2002-2005. (In Polish)

37. Sajjad, M.; Kim, K.S. Studies on the interactions of $\mathrm{Ca}^{2+}$ and $\mathrm{Mg}^{2+}$ with EPS and their role in determining the physicochemical characteristics of granular sludges in SBR system. Process Biochem. 2015, 50, 966-972. [CrossRef]

38. APHA. Standard Methods for the Examination of Water and Wastewater, 21st ed.; American Public Health Association: Washington, DC, USA, 2005.

39. Kristensen, G.H.; Jørgensen, P.E.; Henze, M. Characterization of functional microorganism groups and substrate in activated sludge and wastewater by AUR, NUR and OUR. Water Sci. Technol. 1992, 25, 43-57. [CrossRef]

40. Zielińska, M.; Bernat, K.; Cydzik-Kwiatkowska, A.; Wojnowska-Baryła, I. Respirometric activity of activated sludge in sequencing batch reactor depending on substrate and dissolved oxygen concentration. Environ. Prot. Eng. 2012, 38, 41-49. [CrossRef]

41. Arrojo, B. Advanced Systems for Biological Treatment of High Nitrogen-Loaded Wastewater. Ph.D. Thesis, University Santiago de Compostela, Santiago de Compostela, Spain, 2007; pp. 1-312.

42. Li, A.-J.; Li, X.-Y.; Yu, H.-Q. Aerobic sludge granulation facilitated by activated carbon for partial nitrification treatment of ammonia-rich wastewater. Chem. Eng. J. 2013, 218, 253-259. [CrossRef]

43. Wang, S.-G.; Gai, L.-H.; Zhao, L.-J.; Fan, M.-H.; Gong, W.-X.; Gao, B.-Y.; Ma, Y. Aerobic Granules for Low-Strength Wastewater Treatment: Formation, Structure, and Microbial Community. J. Chem. Technol. Biotechnol. 2009, 84, 1015-1020. [CrossRef]

44. Jiang, H.L.; Tay, J.H.; Liu, Y.; Tay, S.T. $\mathrm{Ca}^{2+}$ augmentation for enhancement of aerobically grown microbial granules in sludge blanket reactors. Biotechnol. Lett. 2003, 25, 95-99. [CrossRef]

45. Cydzik-Kwiatkowska, A.; Rusanowska, P.; Głowacka, K. Operation mode and external carbon dose as determining factors in elemental composition and morphology of aerobic granules. Arch. Environ. Prot. 2016, 42, 74-79. [CrossRef]

46. Wu, D.; Zhang, Z.; Yu, Z.; Zhu, L. Optimization of F/M for stability of aerobic granular process via quantitative sludge discharge. Biores. Technol. 2018, 252, 150-156. [CrossRef]

47. Kończak, B.; Miksch, K. Influence of extracellular polymeric substances on aerobic granulation. Sci. Rev. Eng. Environ. Sci. 2016, 25, 425-432.

48. Sarma, S.J.; Tay, J.-H. Carbon, nitrogen and phosphorus removal mechanisms of aerobic granules. Crit. Rev. Biotechnol. 2018, 38, 1077-1088. [CrossRef] [PubMed] 
49. Filali, A.; Manas, A.; Mercade, M.; Bessière, Y.; Biscans, B.; Spérandio, M. Stability and performance of two GSBR operated in alternating anoxic/aerobic or anaerobic/aerobic conditions for nutrient removal. Biochem. Eng. J. 2012, 67, 10-19. [CrossRef]

50. Manas, A.; Sperandio, M.; Decker, F.; Biscans, B. Location and chemical composition of microbially induced phosphorus precipitates in anaerobic and aerobic granular sludge. Environ. Technol. 2012, 33, $2195-2209$. [CrossRef] [PubMed]

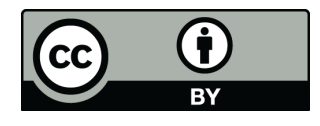

(C) 2020 by the authors. Licensee MDPI, Basel, Switzerland. This article is an open access article distributed under the terms and conditions of the Creative Commons Attribution (CC BY) license (http://creativecommons.org/licenses/by/4.0/). 